\title{
KUALITAS SEMI-REFINED CARRAGEENAN CHIPS PADA RUMPUT LAUT MERAH Kappaphycus alvarezii YANG DIKERINGKAN DENGAN MENGGUNAKAN CABINET DRYER
}

\author{
Brian A. R. Dumondor ${ }^{1}$, Daisy M. Makapedua ${ }^{2}$, Nurmeilita Taher ${ }^{2}$, \\ Verly Dotulong ${ }^{2}$, Eunike L. Mongi ${ }^{2}$, Roike I. Montolalu ${ }^{2}$ \\ ${ }^{1)}$ Mahasiswa pada Program Studi Teknologi Hasil Perikanan FPIK UNSRAT Manado. 95115. \\ ${ }^{2)}$ Staf pengajar pada Program Studi Teknologi Hasil Perikanan FPIK UNSRAT Manado. 95115. \\ E-mail: briandumondor@yahoo.com
}

\begin{abstract}
ABSTRAK
Rumput laut merah Kappaphycus alvarezii merupakan salah satu komoditas ekspor dan program utama revitalisasi perikanan yang berperan penting dalam peningkatan kesejahteraan masyarakat karena mengandung zat karaginan yang merupakan bahan campuran dalam industri pangan dan non pangan. Penelitian ini bertujuan untuk mengetahui kualitas semi-refined carrageenan rumput laut merah Kappaphycus alvarezii yang dikeringkan dengan menggunakan cabinet dryer. Penelitian ini menggunakan konsentrasi larutan $\mathrm{KOH} 8 \%$ serta menggunakan metode pengeringan cabinet dryer dengan suhu $50-60^{\circ} \mathrm{C}$. Hasil penelitian ini menunjukkan bahwa kedua perlakuan pengeringan A1 (12 Jam) dan A2 (24 Jam) memenuhi syarat yang ditentukan oleh FAO. Tetapi perlakuan terbaik adalah perlakuan A2 (24 Jam) dimana kadar air yang didapat adalah 6,75\%, kadar abu 25,04\%, kadar abu tidak larut asam 0,04\%, viskositas $14,52 \mathrm{cP}$, rendemen $26 \%$ dan memiliki nilai $\mathrm{pH} 9,85$.
\end{abstract}

Kata kunci: Semi-refined carrageenan chips, Kappaphycus alvarezii, Pengeringan, cabinet dryer, $\mathrm{KOH}$.

\section{PENDAHULUAN}

Indonesia adalah negara kepulauan terbesar di dunia dengan lebih dari 17.500 pulau. Wilayah laut merupakan $75 \%(5,8$ juta $\mathrm{km}^{2}$ ) dari total wilayah Indonesia dengan garis pantai terbesar kedua (sekitar $81.000 \mathrm{~km}$ ) di dunia setelah Kanada. Sebanyak 15 provinsi di Indonesia sedang terlibat dalam budidaya rumput laut (Akrim, 2014). Komoditas rumput laut Kappaphycus alvarezii mempunyai prospek yang cerah dalam perdagangan untuk kebutuhan dalam negeri maupun luar negeri.

Kappaphycus alvarezii merupakan jenis rumput laut yang banyak dicari untuk kepentingan industri makanan, obat-obatan dan kosmetik di dunia karena mengandung zat karaginan yang merupakan bahan campuran (additives) dalam industri pangan dan non pangan (farmasi, pabrikasi logam, keramik, pelapis (coating) (Amiluddin, 2007). Dengan beberapa sifat yang dimiliki, karaginan dapat berfungsi sebagai gelling agent, thickener, viscosifiying agent, maupun sebagai emulsifiying agent (Anggagiredja $d k k$. 2009).

Di pasar Internasional rumput laut yang berasal dari Indonesia masih dihargai rendah, hal tersebut disebabkan karena mutunya rendah. Selain itu, dari produktivitas rendemen hasil olahan masih rendah dan kekuatan gel karaginan yang dihasilkan masih belum memenuhi standar mutu (Aslan, 1998 dalam Ega $d k k$, 2016). Indonesia sebagai salah satu negara penghasil karaginan (karagenofita), hanya mampu mensuplai sekitar $18 \%$ kebutuhan karaginan pasar dunia, suatu level produksi yang jauh lebih rendah bila dibandingkan dengan produsen karagenofita lainnya, seperti Filipina, yang dapat mensuplai pasar dunia sekitar 62\% (Naiu, 2011 dalam Harun dkk, 2013). Kondisi di atas memberikan peluang untuk membangun industri rumput laut yang tidak hanya menghasilkan produk dasar, tetapi sampai pada produk akhir yang siap pakai (Anggadiredja dkk, 2009). Tujuan dari penelitian ini adalah untuk mengetahui kualitas semi-refined carrageenan chips rumput laut merah Kappaphycus alvarezii yang dikeringkan dengan menggunakan cabinet dryer. 


\section{METODE PENELITIAN}

\section{Bahan dan Alat}

Bahan baku penelitian ini adalah rumput laut merah Kappaphycus alvarezii yang diambil dari pembubidaya rumput laut di Desa Arakan Minahasa Selatan dengan umur panen 6-8 minggu, air, akuades, dan kalium hidroksida $(\mathrm{KOH})$ dengan konsentrasi $8 \%$.

Alat-alat yang digunakan dalam penelitian ini adalah timbangan, kompor minyak tanah, kuali (belanga), sendok, cool box, wadah, wadah berlubang, timer, pengaduk, kertas ph, thermometer, gelas ukur, gelas piala, desikator, oven, cawan porselen, tanur, $\mathrm{pH}$ Meter, sarung tangan dan alat pengering buatan (cabinet dryer).

\section{Perlakuan}

Perlakuan yang dilakukan dalam penelitian adalah sebagai berikut:

Pengeringan Rumput Laut Merah Segar dengan menggunakan pengering buatan (cabinet dryer) dengan sumber panas dari kompor yang berkisar $50-60^{\circ} \mathrm{C}$ selama:
A1. 12 jam
A2. 24 jam

\section{Tata Laksana Penelitian}

\section{Pengeringan Rumput Laut Merah Segar}

Bahan baku yang digunakan adalah rumput laut merah yang diperoleh dari desa Arakan, ditaruh dalam cool box dan dibawa ke Laboratorium Teknologi Penanganan dan Pengolahan Hasil Perikanan, Fakultas Perikanan dan Ilmu Kelautan Universitas Sam Ratulangi Manado. Rumput laut yang telah dibawa ke Laboratorium dicuci dengan air bersih yang mengalir, untuk menghilangkan kotoran yang melekat seperti lumpur, garam, dan lain-lain. Rumput laut yang telah bersih dikeringkan dengan alat cabinet dryer menggunakan temperatur $50-60^{\circ} \mathrm{C}$ dengan menggunakan sumber panas dari kompor selama 12 dan 24 jam.

\section{Pengolahan Semi-refined carrageenan (SRC) chips}

Di bawah ini adalah tahapan untuk membuat SRC berbentuk chips.

1. Perendaman dalam alkali panas: sampel rumput laut yang telah dikeringkan, ditimbang sebanyak $250 \mathrm{gr}$ dan dicuci dengan air tawar kemudian dilakukan perendaman dengan alkali panas. Larutan alkali yang digunakan adalah larutan $\mathrm{KOH}$ dengan konsentrasi $8 \%$ dan jumlahnya sebanyak 6 kali dari berat rumput laut yang diolah. Larutan $\mathrm{KOH}$ disiapkan dengan memasukkan kristal $\mathrm{KOH}$ ke dalam air dan diaduk sampai larut. Larutan $\mathrm{KOH}$ dipanaskan sampai suhu $70-80^{\circ} \mathrm{C}$, lalu rumput laut dimasukkan ke dalamnya. Perendaman atau pemasakan ini dilakukan menggunakan gelas piala yang dimasukkan ke dalam kuali selama 2-3 jam dan suhu diatur sekitar $70^{\circ} \mathrm{C}$.

2. Pencucian: setelah pemasakan selama 2-3 jam dalam larutan $\mathrm{KOH}$ panas, rumput laut diangkat kemudian dicuci. Pencucian dilakukan berulang-ulang dengan air tawar hingga $\mathrm{pH}$ netral.

3. Pemotongan dan pengeringan: rumput laut yang telah dicuci sampai netral, lalu ditiriskan dan siap dikeringkan. Rumput laut dipotong hingga berukuran sekitar $3 \mathrm{~cm}$ agar pengeringan lebih efektif. Setelah itu dilakukan proses pengeringan dengan menggunakan cabinet dryer dengan suhu $50-60^{\circ} \mathrm{C}$ selama 12 jam dengan sumber panas dari kompor minyak tanah.

4. Pengemasan: Semi-refined carrageenan yang telah berbentuk chips tersebut dikemas ke dalam kantung plastik, atau karton.

\section{HASIL DAN PEMBAHASAN}

\section{Kadar Air}

Pengujian kadar air dimaksudkan untuk mengetahui seberapa besar kandungan air dalam karaginan. Kadar air menunjukkan ketahanan karaginan terhadap mikroba. Penurunan nilai kadar air dari rumput laut segar sampai dikeringkan dengan cabinet dryer bisa dilihat pada Gambar 1.

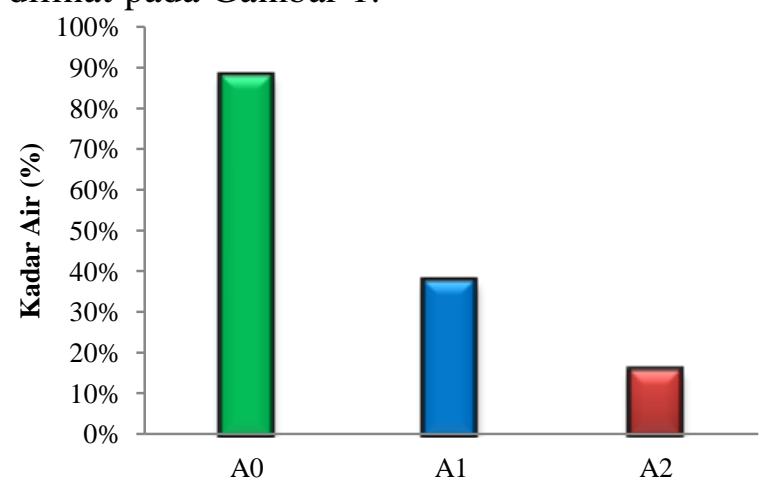

Gambar 1. Penurunan Nilai Kadar Air Rumput Laut Merah (Kappaphycus alvarezii).

Ket. A0 (Rumput Laut Segar); A1 (Rumput Laut yang dikeringkan selama $12 \mathrm{Jam}$ ); $\quad$ A2 (Rumput Laut yang dikeringkan selama $24 \mathrm{Jam}$ ). 
Pada Gambar 1, menunjukkan penurunan nilai kadar air dari rumput laut segar ke rumput laut kering. Kadar air rumput laut segar adalah $88 \%$. Nilai kadar air dengan pengeringan menggunakan cabinet dryer selama 12 jam yaitu $37,25 \%$ sedangkan pengeringan selama 24 jam yaitu $15,25 \%$. Untuk hasil analisa kadar air pada semi-refined carrageenan chips dapat dilihat pada Gambar 2.

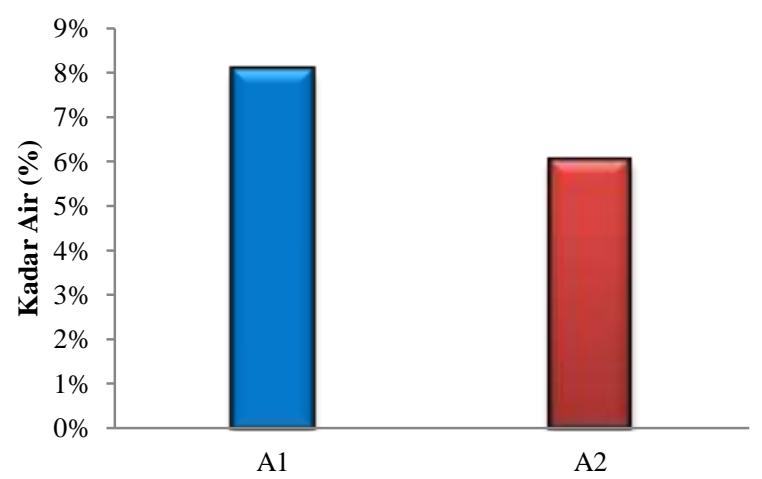

Gambar 2. Nilai Kadar Air Semi-refined carrageenan chips pada Rumput Laut Merah (Kappaphycus alvarezii).

Ket. A1 (Semi-refined carrageenan dari rumput laut yang dikeringkan selama $12 \mathrm{Jam}$ ); A2 (Semi-refined carrageenan dari rumput laut yang dikeringkan selama $24 \mathrm{Jam}$ ).

Berdasarkan gambar 2 di atas, kadar air SRC rumput laut merah dari rumput laut yang dikeringkan selama 12 jam (A1) lebih tinggi dibandingkan dengan rumput laut yang dikeringkan selama 24 jam (A2). Nilai kadar air dari rumput laut merah SRC kering dengan perlakuan A1 (12 jam) pada temperatur 50$60^{\circ} \mathrm{C}$ yaitu $8,25 \%$, sedangkan perlakuan A2 (24 jam) sebesar 6,75\%.

Kadar air yang didapat dari penelitian ini lebih rendah bila dibandingkan dengan penelitian yang dilakukan oleh Tamaheang $d k k$. (2017) yang berkisar antara 15,75-17,25\%. Rendahnya kadar air pada penelitian ini diduga disebabkan oleh larutan pengekstrak serta konsentrasi yang digunakan dimana pada penelitian Tamaheang $d k k$. (2017) menggunakan larutan $\mathrm{NaOH}$. Pada penelitian lainnya, Panggabean $d k k$. (2018) mendapatkan nilai kadar air sebesar 5\% pada konsentrasi $\mathrm{KOH} \mathrm{4 \%}$ sedangkan Erjanan $d k k$. (2017) mendapatkan nilai kadar air yang berkisar antara 22,37$17,75 \%$ pada konsentrasi $\mathrm{KOH}$ 0,01-0,15\%. Menurut Ega $d k k$. (2016), perlakuan konsentrasi $\mathrm{KOH}$ berpengaruh nyata terhadap kadar air. Semakin tinggi konsentrasi $\mathrm{KOH}$ maka semakin rendah kadar air karaginan, hal ini disebabkan oleh kemampuan $\mathrm{KOH}$ dalam mengekstrak dan menghambat terjadinya peningkatan air dalam molekul rumput laut merah sehingga kadar air menjadi berkurang.

Kisaran standar mutu kadar air karaginan yang ditetapkan oleh FAO yaitu maksimum 12\% (FAO and WHO, 2014). Dari hasil penelitian ini menunjukkan bahwa kadar air SRC yang dikeringkan dengan cabinet dryer selama 12 dan 24 jam memenuhi standar yang telah ditentukan oleh FAO.

\section{Kadar Abu}

Hasil pengamatan Kadar Abu SRC rumput laut merah (Kappaphycus alvarezii) dapat dilihat pada Tabel 1.

Tabel 1. Hasil nilai kadar abu (\%) pada semi-refined carragenan chips rumput laut merah (Kappaphycus alvarezii).

\begin{tabular}{cc}
\hline Perlakuan & Kadar Abu (\%) \\
\hline A1 (12 JAM) & 19,36 \\
A2 (24 JAM) & 25,04 \\
\hline
\end{tabular}

Pada perlakuan A1 (12 Jam) kadar abu yang dihasilkan yaitu $19,36 \%$, sedangkan pada perlakuan A2 (24 Jam) kadar abu yang dihasilkan yaitu $25,04 \%$. Nilai kadar abu yang dihasilkan dalam penelitian ini lebih rendah dibandingkan dengan hasil penelitian yang dilakukan oleh Ega $d k k$. (2016) yaitu 29,88\% dengan konsentrasi yang sama, sedangkan Panggabean $d k k$. (2018) mendapatkan nilai kadar abu sebesar $55,27 \%$ pada konsentrasi $\mathrm{KOH} 4 \%$. Dari hasil di atas menunjukkan bahwa konsentrasi $\mathrm{KOH}$ berpengaruh terhadap tinggi rendahnya kadar abu pada tiap semirefined carrageenan. Selain itu, kadar abu dipengaruhi oleh banyaknya kandungan mineral di lokasi pembudidayaan rumput laut dan tinggi rendahnya salinitas di perairan tersebut (Harun $d k k, 2013)$. Menurut standarisasi karaginan komersial yang ditetapkan oleh FAO dengan syarat mutu kadar abu maksimum 15-40\% maka karaginan yang dihasilkan dalam penelitian ini telah memenuhi syarat mutu yang ditentukan.

\section{Kadar Abu Tidak Larut Asam}

Hasil pengamatan kadar abu tidak larut asam SRC rumput laut merah (Kappaphycus alvarezii) dapat dilihat pada Tabel 2 .

Dari hasil penelitian ini, kedua sampel sesuai dengan persyaratan yang ditetapkan oleh FAO yaitu maksimal $1 \%$. Nilai yang didapat lebih rendah jika dibandingkan dengan penelitian Asikin $d k k$. (2015) yang melaporkan hasil kadar abu tak larut asam sebesar 1,96$3,81 \%$. Hal ini menunjukkan bahwa kebersihan 
pengolahan semi-refined carrageenan yang dilakukan pada penelitian ini cukup terjaga dan terhindar dari kontaminasi benda asing. Menurut Wenno $d k k$. (2012), rendahnya kadar abu tidak larut asam ini menunjukkan karaginan yang dihasilkan pada penelitian ini tidak banyak terkontaminasi selama proses penanganan bahan baku dan pengolahan. Pendapat tersebut didukung oleh Basmal $d k k$. (2003) yang juga menyatakan bahwa kadar abu tidak larut asam yang rendah menunjukkan bahwa hanya sedikit kontaminasi residu mineral atau logam yang tidak dapat larut dalam asam pada suatu produk seperti silika yang ditemukan di alam.

Tabel 2. Hasil nilai kadar abu tidak larut asam (\%) pada semi-refined carragenan chips rumput laut merah (Kappaphycus alvarezii).

\begin{tabular}{cc}
\multicolumn{2}{c}{ laut merah (Kappaphycus alvarezii). } \\
\hline Perlakuan & Kadar Abu Tidak Larut Asam (\%) \\
\hline A1 (12 JAM) & 0,03 \\
A2 (24 JAM) & 0,04 \\
\hline
\end{tabular}

\section{Viskositas}

Nilai viskositas pada penelitian ini bisa dilihat pada Tabel 3 .

Tabel 3. Hasil nilai viskositas (cP) pada semirefined carrageenan chips rumput laut merah (Kappaphycus alvarezii).

\begin{tabular}{cc}
\hline Perlakuan & Viskositas (cP) \\
\hline A1 (12 JAM) & 217,80 \\
A2 (24 JAM) & 14,52 \\
\hline
\end{tabular}

Nilai viskositas pada perlakuan A1 (12 Jam) sangat tinggi yaitu $217,80 \mathrm{cP}$, sedangkan untuk perlakuan A2 (24 Jam) nilai viskositas yang dihasilkan yaitu $14,52 \mathrm{cP}$. Nilai viskositas yang diperoleh dari penelitian ini cukup tinggi jika dibandingkan dengan penelitian Bunga $d k k$. (2013) yaitu 60cP. Harun $d k k$. (2013) mengemukakan bahwa viskositas karaginan yang dihasilkan dari rumput laut dengan kadar air tinggi lebih rendah dibandingkan viskositas karaginan yang dihasilkan dari rumput laut dengan kadar air rendah. Nilai viskositas yang didapat dari penelitian ini masih memenuhi standar persyaratan minimum viskositas karaginan yang ditetapkan oleh FAO, yaitu minimal bernilai $5 \mathrm{cP}$.

\section{Rendemen Semi-refined Carrageenan}

Rendemen adalah perbandingan jumlah (kuantitas) karaginan yang dihasilkan dari ekstraksi rumput laut. Kualitas karaginan yang dihasilkan biasanya berbanding terbalik dengan jumlah rendemen yang dihasilkan (Wiraswanti, 2008). Semakin tinggi nilai rendemen yang dihasilkan maka semakin rendah mutu yang didapatkan. Rendemen Semi-refined carrageenan chips rumput laut merah Kappaphycus alvarezii penelitian ini dapat dilihat pada Gambar 3.

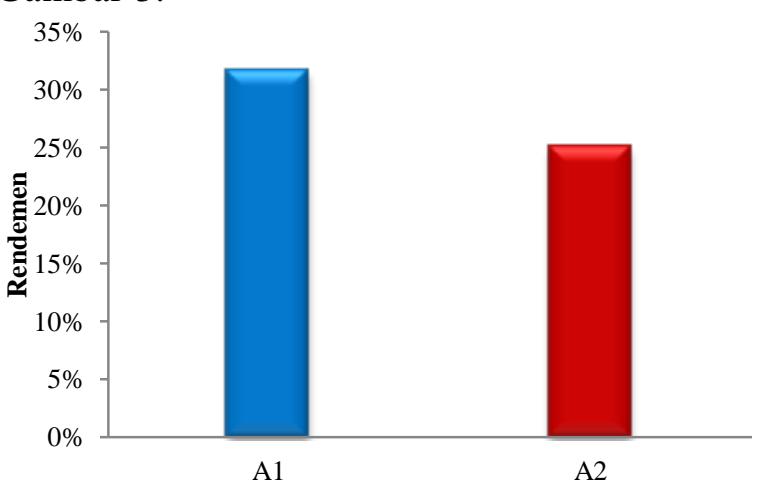

Gambar 3. Penurunan rendemen SRC chips pada Rumput Laut Merah (Kappaphycus alvarezii).

Ket.: A1 (SRC pengeringan selama 12 Jam); A2 (SRC pengeringan selama $24 \mathrm{Jam}$ )

Pada perlakuan A1 (12 Jam) rendemen yang dihasilkan adalah $31,6 \%$, sedangkan pada perlakuan A2 (24 Jam) rendemen yang dihasilkan adalah $26 \%$. Berdasarkan data rendemen semi-refined carrageenan hasil penelitian dapat dilihat bahwa pengeringan selama 12 jam menghasilkan rendemen yang lebih tinggi jika dibandingkan dengan pengeringan selama 24 jam. Konsentrasi $\mathrm{KOH}$ yang digunakan juga mempengaruhi rendemen yang dihasilkan karena semakin tinggi konsentrasi $\mathrm{KOH}$ selama proses alkalisasi berlangsung, menyebabkan pHnya semakin tinggi sehingga kemampuan $\mathrm{KOH}$ dalam mengekstrak semakin besar (Hudha $d k k, 2012$ dalam Ega $d k k, 2016)$. Dari hasil penelitian ini menunjukkan bahwa rendemen semi-refined carrageenan chips dari Kappaphycus alvarezii baik yang dikeringkan selama 12 jam atau 24 jam masih memenuhi standar SNI yaitu tidak kurang dari $25 \%$.

\section{Nilai pH}

Nilai pH (derajat keasaman) merupakan suatu indeks kadar ion hidrogen $(\mathrm{H}+)$ yang mencirikan keseimbangan asam basa dan memiliki kisaran nilai antara 1 sampai dengan 14 . Hasil analisa nilai $\mathrm{pH}$ semi-refined carrageenan dari pengeringan rumput laut selama 12 jam adalah 10,18 , sedangkan nilai $\mathrm{pH}$-semi-refined carrageenan dari pengeringan rumput laut selama 24 jam adalah 9,85. Nilai $\mathrm{pH}$ yang didapat dari penelitian ini bisa dilihat pada Tabel 4 . 
Tabel 4. Nilai pH (derajat keasaman) pada semirefined carrageenan rumput laut merah (Kappaphycus alvarezii).

\begin{tabular}{lrrrr}
\hline Perlakuan & \multicolumn{1}{c}{ Ulangan 1 } & \multicolumn{1}{c}{ Ulangan 2 } & Total & Rata-rata \\
\hline A1 (12 Jam) & 10,20 & 10,17 & 20,37 & 10,18 \\
A2 (24 Jam) & 9,98 & 9,72 & 19,70 & 9,85 \\
\hline
\end{tabular}

Nilai $\mathrm{pH}$ yang didapat dari penelitian ini sedikit lebih besar dari penelitian yang dilakukan oleh Panggabean dkk. (2018) yaitu 8.69 dengan konsentrasi $\mathrm{KOH} 4 \%$. Hal ini menyatakan bahwa semakin tinggi konsentrasi $\mathrm{KOH}$ maka nilai $\mathrm{pH}$ pun akan semakin tinggi. Ferdiansyah dkk. (2017) menjelaskan bahwa nilai $\mathrm{pH}$ yang dimiliki oleh karagenan tergantung dari proses produksi seperti lama pemasakan dan konsentrasi alkali yang ditambahkan. Dari hasil penelitian di atas, nilai $\mathrm{pH}$ menunjukkan semua sampel karagenan memenuhi persyaratan yang ditetapkan oleh FAO yaitu antara $8-11$.

\section{KESIMPULAN DAN SARAN}

\section{Kesimpulan}

1. Kualitas kadar air semi-refined carrageenan chips yang dikeringkan dengan menggunakan alat cabinet dryer sudah memenuhi standar yang ditetapkan oleh FAO yaitu maksimum $12 \%$.

2. Kadar abu karaginan pada penelitian ini berkisar antara 19,36-25,04\% menunjukkan bahwa kadar abu yang diperoleh memenuhi standar mutu karaginan yang ditetapkan FAO sebesar $15-40 \%$ sedangkan untuk nilai kadar abu tidak larut asam yaitu $0,03 \%$ dan $0,04 \%$ dan masih memenuhi standar yang ditentukan FAO (maks 1\%).

3. Dengan tingkat konsentrasi $\mathrm{KOH} 8 \%$, rendemen semi refined carrageenan chips yang didapat dari proses pengeringan cabinet dryer memenuhi standar yang ditetapkan SNI 01-2690-1998 tentang kadar karaginan dari rumput laut.

4. Nilai $\mathrm{pH}$ yang didapat dari pengeringan 12 jam yaitu 10,18, sedangkan untuk 24 jam yaitu 9,85. Secara umum nilai $\mathrm{pH}$ semirefined carrageenan chips yang dikeringkan menggunakan alat cabinet dryer adalah basa.

5. Nilai viskositas semi-refined carrageenan yang dikeringkan dengan alat cabinet dryer di atas standar yang ditentukan oleh FAO (> $5 \mathrm{cP})$.

6. Secara keseluruhan, kualitas semi-refined carrageenan chips yang dikeringkan dengan alat cabinet dryer memenuhi standar yang telah ditetapkan.

\section{Saran}

1. Perlu dilakukan penelitian lebih lanjut untuk mengetahui tentang kadar sulfat serta kekuatan gel terhadap karaginan dari rumput laut merah Kappaphycus alvarezii yang dikeringkan dengan cabinet dryer.

2. Perlu dilakukan penelitian dengan menggunakan beragam konsentrasi $\mathrm{KOH}$ untuk mengetahui serta membandingkan kualitas karaginan yang dihasilkan.

\section{DAFTAR PUSTAKA}

Akrim, D. H. 2014. The Seaweed Business Development in Indonesia. Journal of Shipping and Ocean Engineering No. 4, p 198-202.

Amiluddin, N. M. 2007. Kajian Pertumbuhan dan Kandungan Karaginan Rumput Laut Kappaphycus alvarezii yang Terkena Penyakit Ice Ice Di Perairan Pulau Pari Kepulauan Seribu. Skripsi. Institut Pertanian Bogor.

Anggadiredja, J. T., Zatnika, A., Purwoto, H dan Istini, S. 2009. Rumput Laut. Penebar Swadaya.

Asikin, A., Kusumaningrum, I dan Sutono, D. 2015. Ekstraksi dan Karakterisasi Sifat Fungsional Karaginan Kappaphycus alvarezii Asal Pesisir Kabupaten Kutai Timur. Jurnal Ilmu dan Teknologi Kelautan Tropis, Vol. 7, No. 1, Hal. 49-58, Juni 2015.

Basmal, J., Syarifuddin, dan Ma'ruf, W.F. 2003. Pengaruh konsentrasi larutan potasium hidroksida terhadap mutu kappa-karaginan yang diekstraksi dari Eucheuma cottonii. Jurnal Penelitian Perikanan Indonesia. Vol. 9, No.5, Hal 95-103.

Bunga, S. M., Montolalu, R. I., Harikedua, J. W. Montolalu, L. A. D. Y., Watung, A. H dan Taher, N. 2013. Karakteristik Sifat Fisika Kimia Karaginan Rumput Laut Kappaphycus alvarezii Pada Berbagai Umur Panen Yang Diambil Dari Daerah Perairan Desa Arakan Kabupaten Minahasa Selatan. Jurnal Media Teknologi Hasil Perikanan, Volume 1, No. 2, Hal. 5458, Agustus 2013.

Ega, L., Lopulalan, C. G. C dan Meiyasa, F. 2016. Kajian Mutu Karaginan Rumput Laut Eucheuma cottonii Berdasarkan Sifat Fisiko-Kimia pada Tingkat Konsentrasi Kalium Hidroksida $(\mathrm{KOH})$ yang Berbeda. Jurnal Aplikasi Teknologi Pangan Volume 5, No.2, Hal. 38-44, 2016.

Erjanan, S., Dotulong, V dan Montolalu, R. I. 2017. Mutu Karaginan dan Kekuatan Gel Dari Rumput Laut Merah Kappaphycus alvarezii. Jurnal Media Teknologi Hasil Perikanan. Vol. 5, No.2, Hal 130133.

Ferdiansyah, R., Yohana, A. C dan Abdassah, M. 2017. Karakterisasi Kappa Karaginan dari Eucheuma cottonii Asal Perairan Kepulauan Natuna dan Aplikasinya Sebagai Matriks Tablet Apung. Indonesian Journal of Pharmaceutical Science and Technology. Volume.6, No.1, Hal. 14-26. 
Harun, M., Montolalu, R. I, dan Suwetja, I. K. 2013. Karakteristik Fisika Kimia Karaginan Rumput Laut Jenis Kappaphycus alvarezii Pada Umur Panen Yang Berbeda di Perairan Desa Tihengo Kabupaten Gorontalo Utara. Jurnal Media Teknologi Hasil Perikanan, Volume 1, No. 1, Hal. 7-12.

Panggabean, J. E., Dotulong, V., Montolalu, R. I., Damongilala, L., Harikedua, S. D dan Makapedua, D. M. 2018. Ekstraksi Karagenan Rumput Laut Merah (Kappaphycus alvarezii) Dengan Perlakuan Perendaman Dalam Larutan Basa. Jurnal Media Teknologi Hasil Perikanan. Vol. 6, No.3, Hal 258263.

Tamaheang, T., Makapedua, D. M dan Berhimpon, S. 2017. Kualitas Rumput Laut Merah (Kappaphycus alvarezii) Dengan Metode Pengeringan Sinar
Matahari Dan Cabinet Dryer Serta Rendemen SemiRefined Carrageenan (SRC). Jurnal Media Teknologi Hasil Perikanan. Volume.5, No.2, Hal. 152-157, Agustus 2017.

Wenno, M. R., Thenu, J. L dan Lopulalan, C. G. C. 2012. Karakteristik Kappa Karaginan Kappaphycus alvarezii Pada Berbagai Umur Panen. Jurnal Pascapanen dan Bioteknologi Perikanan Volume. 7 No. 1, Hal. 61-67.

Wiraswanti, I. 2008. Pemanfaatan Karagenan dan Kitosan dalam Pembuatan Bakso Ikan Kurisi (Nemipterus nematophorus) pada Penyimpanan Suhu Dingin dan Beku. Skripsi. Institut Pertanian Bogor. Bogor. 95 hlm. 